\title{
Analisis Daya Saing dan Faktor-Faktor yang Mempengaruhi Ekspor Produk Alas Kaki Indonesia ke Amerika Serikat Ditinjau dalam Perspektif Ekonomi Islam
}

\author{
Nurlaili \\ Fakultas Ekonomi dan Bisnis Islam, UIN Raden Intan Lampung \\ Email Korespondensi: nurlaili@ radenintan.ac.id
}

\begin{abstract}
Abstrak
Alas kaki merupakan salah satu komoditas unggulan ekspor Indonesia. Namun, capaian ini masih jauh dengan target yang dituju oleh kementerian perindustrian Indonesia yaitu pertumbuhan sebesar $10 \%$ setiap tahunnya. Tujuan penelitian ini adalah: untuk menganalisis daya saing Indonesia terhadap produk alas kaki yang diekspor ke Amerika Serikat, Faktor-faktor yang mempengaruhi ekspor alas kaki Indonesia ke Amerika Serikat serta pandangan ekonomi Islam terkait daya saing dan faktor-faktor yang mempengaruhi ekspor. Metode yang digunakan adalah metode kuantitatif. Menggunakan analisis RCA dan analisis regresi linear berganda. Data yang digunakan adalah data sekunder. Hasil penelitian menunjukkan bahwa indeks RCA > 1, maka ekspor produk alas kaki Indonesia ke Amerika Serikat berdaya saing di dunia. Secara parsial, GDP AS dan nilai tukar berpengaruh positif dan signifikan terhadap ekspor alas kaki Indonesia ke AS, harga berpengaruh positif dan tidak signifikan terhadap ekspor alas kaki Indonesia ke AS, dan produksi berpengaruh negatif dan tidak signifikan terhadap ekspor alas kaki Indonesia ke AS. Secara simultan, GDP AS, nilai tukar, harga dan produksi secara bersama-sama berpengaruh terhadap ekspor alas kaki Indonesia ke Amerika Serikat. Persaingan dalam perspektif ekonomi Islam sangat dianjurkan, namun harus secara sehat sebagaimana dijelaskan di Q.S AlBaqarah:148, setiap negara dilarang untuk berbuat kecurangan salah satunya adalah teknik dumping.
\end{abstract}

Kata kunci: RCA, GDP AS, Nilai Tukar, Harga, Produksi, Ekspor AlasKaki, Perspektif Ekonomi Islam.

\begin{abstract}
Footwear is one of Indonesia's leading export commodities. However, this achievement is still far from the target set by the Indonesian Ministry of Industry, namely growth of 10\% annually. The aim this study are to analysis of Indonesia's competitiveness of footwear products exported to the United States, factors affect Indonesian footwear exports to the US and the Islamic economy view competitiveness and the factors affecting exports. The method used is a quantitative method. Using the RCA analysis and multiple linear regression analysis. The data taken from this research is secondary data. The results showed that the $R C A$ index $>1$, then the export of Indonesian footwear products to the US was competitive in the world. Partially, US GDP and the exchange rate have a positive and significant effect on Indonesian footwear exports to the US, prices have a positive and insignificant effect on Indonesian footwear exports to the US, and production has a negative and insignificant effect on Indonesian footwear exports to the US. Simultaneously, US GDP, exchange rates, prices and production together influence the export of Indonesian footwear to the US. Competition from an Islamic economic perspective is highly recommended, but it must be healthy as explained in Q.S Al-Baqarah:148 where every country is prohibited from committing fraud, one of which is the dumping technique.
\end{abstract}

Keywords: RCA, US GDP, Exchange Rates, Prices, Production, Footwear Exports, Islamic Economic Perspective

Saran sitasi: Nurlaili. (2021). Analisis Daya Saing dan Faktor-Faktor yang Mempengaruhi Ekspor Produk Alas Kaki Indonesia ke Amerika Serikat Ditinjau dalam Perspektif Ekonomi Islam. Jurnal Ilmiah Ekonomi Islam, 7(02), 1019-1029. doi: http://dx.doi.org/10.29040/jiei.v7i2.2385

DOI: http://dx.doi.org/10.29040/jiei.v7i2.2385

\section{PENDAHULUAN}

Dinamika kondisi ekonomi dunia yang terus berubah dan menimbulkan berbagai dampak bagi sejumlah negara, termasuk Indonesia, memaksa setiap negara untuk memiliki strategi antisipasi agar mampu bertahan di kancah persaingan internasional. Krisis 
global yang melanda sejumlah negara maju telah menimbulkan pengaruh dalam aktivitas perdagangan internasional, di mana umumnya negara berkembang mengekspor sebagian besar komoditi lokalnya ke negara maju. Indonesia merupakan suatu negara yang menganut sistem perekonomian terbuka, artinya bahwa negara tersebut melakukan transaksi ekonomi dengan pihak luar negeri atau yang sering disebut dengan perdagangan internasional yang tujuan utamanya adalah untuk meningkatkan kesejahteraan serta memenuhi kebutuhan dalam negeri.

Perdagangan internasional memberikan keuntungan bagi negara, karena negara bisa menjual barang-barangnya ke luar negeri. Hal ini tentu saja dapat meningkatkan kekayaan dan kesejaheraan penduduknya. Perdagangan internasional terjadi karena adanya perbedaan selera atau pola konsumsi antar negara, dan timbulnya perdagangan internasional terutama sekali karena suatu negara bisa menghasilkan barang tertentu secara lebih efisien daripada negara lain. Sedangkan dalam Islam, perdagangan internasional adalah sama dengan jual beli yaitu transaksi yang dilakukan oleh pihak penjual dan pembeli atas suatu barang dan jasa yang menjadi objek transaksi jual beli. Dalam sejarah Islam, praktik perdagangan internasional yang telah dilakukan Indonesia adalah negara yang sejak lama telah melakukan perdagangan internasional. Peningkatan ekspor baik jumlah maupun jenis barang atau jasa selalu diupayakan atau digalakkan dengan berbagai strategi diantaranya adalah pengembangan ekspor, terutama ekspor non migas, baik barang maupun jasa. Tujuan dari program pengembangan ekspor ini adalah mendukung upaya peningkatan daya saing global produk Indonesia serta meningkatkan peranan ekspor dalam memacu pertumbuhan ekonomi.

Ekspor memiliki peranan yang penting terhadap perekonomian, yaitu sebagai sumber utama devisa terutama untuk pendanaan impor kebutuhan industri dalam negeri, dan sebagai salah satu motor pertumbuhan ekonomi. Ekspor Indonesia pada awalnya didominasi oleh produk-produk minyak dan gas bumi (migas). Sejak tahun 1974 sampai tahun 1986 pembiayaan ekonomi Indonesia banyak tergantung dari penerimaan minyak dan gas bumi. Keadaan oleh Nabi Muhammad SAW dengan membawa dagangan Khodijah hingga ke negeri Syam, inilah yang menjadi bukti bahwa dalam Islam perdagangan itu tidak terbatas hanya terbatas hanya melulu berdagang dalam negeri. Selain itu, dalam surat al-Quraisy dijelaskan bahwa salah satu aktivitas kaum Quraisy pada saat itu adalah melakukan perjalanan saat musim panas dan dingin. yang demikian menyebabkan perekonomian Indonesia sangat peka terhadap perubahan harga migas di pasar internasional.

Pada awalnya pembangunan dipicu oleh ekspor minyak dan gas bumi (migas) yang menyebabkan peningkatan kemampuan produksi. Selain itu pola proteksi perdagangan yang melindungi industri yang berorientasi pada pasar dalam negeri daripada persaingan internasional, telah menarik penanaman modal dalam negeri maupun penanaman modal asing. Dengan jatuhnya harga minyak dan gas bumi pada tahun 1982, maka perkembangan industri menjadi lebih sulit. Dalam menanggapi jatuhnya harga minyak bumi, maka pemerintah meluncurkan serangkaian paket-paket deregulasi. Deregulasi ini dimaksudkan untuk merestrukturisasi ekonomi yang tergantung pada minyak dan gas bumi menuju ekspor komoditi non migas. Hal ini terlihat dari meningkatnya ekspor sumber daya alam serta ekspor industri berbasis pada keunggulan padat karya.

Dalam era globalisasi ekonomi, Indonesia menghadapi proses perdagangan bebas yang berkembang secara terus menerus yang pada akhirnya akan memberikan pengaruh, peluang dan tantangan terhadap aktivitas perdagangan. Dalam pengutamaan sektor atau komoditas pilihan, faktor utama yang mempengaruhi adalah keunggulan komparatif berupa ketersediaan sumber daya yang melimpah. Komoditas tersebut nantinya akan dijadikan sektor unggulan yang dikonsumsi oleh pasar (negara lain) melalui kegiatan ekspor. Ekspor memberikan pemasukan devisa bagi negara bersangkutan yang nantinya dipergunakan untuk membiayai kebutuhan impor maupun pembangunan dalam negeri. Komposisi ekspor Indonesia tidak lagi didominasi oleh sektor migas dan tidak bergantung kepada hasil komoditas pertanian dan pertambangan. Menurut BPS komposisi nilai ekspor Indonesia didominasi oleh sektor nonmigas seperti yang ditunjukkan pada tabel 1 .

Tabel 1. Neraca Perdagangan Ekspor Indonesia tahun 2008-2018 (Ribu ton)

\begin{tabular}{|c|r|r|}
\hline Tahun & \multicolumn{1}{|c|}{ Migas } & \multicolumn{1}{c|}{ Non Migas } \\
\hline 2008 & $44.800,9$ & $310.253,1$ \\
\hline 2009 & $46.072,8$ & $332.926,3$ \\
\hline 2010 & $55.925,1$ & $422.921,7$ \\
\hline 2011 & $59.053,9$ & $523.165,9$ \\
\hline 2012 & $48.446,0$ & $551.690,6$ \\
\hline
\end{tabular}


Jurnal Ilmiah Ekonomi Islam, 7(02), 2021, 1021

\begin{tabular}{|c|r|r|}
\hline Tahun & \multicolumn{1}{|c|}{ Migas } & \multicolumn{1}{c|}{ Non Migas } \\
\hline 2013 & $44.041,9$ & $655.963,2$ \\
\hline 2014 & $41.743,1$ & $507.722,4$ \\
\hline 2015 & $44.964,7$ & $463.862,5$ \\
\hline 2016 & $43.328,8$ & $468.399,3$ \\
\hline 2017 & $42.505,0$ & $503.431,6$ \\
\hline 2018 & $37.055,5$ & $571.852,0$ \\
\hline Jumlah & $\mathbf{5 0 7 . 9 3 7 , 7}$ & $\mathbf{5 . 3 1 2 . 1 8 8 , 6}$ \\
\hline
\end{tabular}

Sumber: BPS (Badan Pusat Statistik)

Pada tabel 1 di atas dapat dilihat perbedaan jumlah ekspor migas dan non migas (dalam satuan ton) terlihat sangat jauh perbedaannya, dari tahun 20082018 jumlah ekspor Indonesia pada sektor migas sebesar 507.937,7 ton sedangkan jumlah ekspor non migas secara keseluruhan mencapai 5.312.188,6 ini menjadi bukti keseriusan dari pemerintah menaikkan dan mengeksplorasi sektor non migas, ditahun 2008 sektor migas hanya mengekspor sebesar 44.800,9 ton dan di sektor non migas mencapai $310.253,1$ ton pada tahun 2008 dan tahun selanjutnya sektor migas masih kalah dengan sektor non migas.

Dengan semakin bertambahnya nilai komoditi non migas yang dapat diekspor, di harapkan perekonomian Indonesia tidak lagi tergantung terhadap harga satu komoditi yaitu migas saja. Sehingga pembangunan secara keseluruhan dapat berjalan dengan baik. Komoditi-komoditi non migas yang cukup potensial untuk diekspor dapat dikelompokan menjadi komoditi primer dan bukan primer. Komoditi primer merupakan hasil dari sektor pertanian dan sektor pertambangan. Sedangkan sektorsektor bukan primer berasal dari sektor industri.

Ekspor mempunyai peranan yang penting terhadap perekonomian, yaitu sebagai sumber utama devisa terutama untuk pendanaan impor kebutuhan industri dalam negeri, dan sebagai salah satu motor penggerak pertumbuhan ekonomi, yang berarti juga peningkatan kesempatan kerja dan pengurangan kemiskinan. Ekspor 10 komoditi unggulan Indonesia di pasar intenasional dari tahun ke tahun terus mengalami peningkatan. Alas kaki merupakan salah satu komoditas unggulan ekspor Indonesia setelah tekstil, elektronik, karet, kelapa sawit, dan produk hasil hutan. Alas kaki merupakan produk seperti sepatu dan sandal yang dipakai untuk melindungi kaki terutama bagian telapak kaki. Alas kaki melindungi kaki agar tidak cedera dari kondisi lingkungan seperti permukaan tanah yang berbatu-batu, berair, udara panas, maupun dingin. Ekspor alas kaki Indonesia secara garis besar dari tahun ke tahun mengalami

peningkatan di pasar internasional, seperti yang ditunjukkan pada Gambar 1.

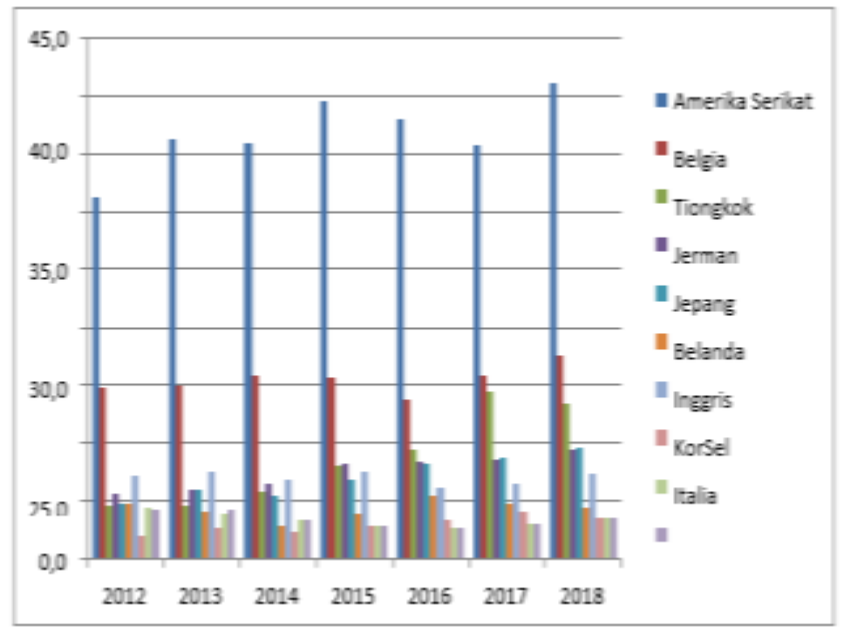

Gambar 1. Nilai Ekspor Alas Kaki

Sumber: UN Comtrade

Pertumbuhan ekspor alas kaki terus mengalami pertumbuhan yang positif, sehingga Indonesia memiliki banyak peluang terhadap kegiatan ekspor alas kaki. Salah satu upaya untuk mendorong perkembangan industri alas kaki, pemerintah Indonesia banyak menggelar pameran untuk menjaring pembeli. Upaya lainnya dengan mengembangkan desain, membuat kemasan lebih menarik, menetapkan harga yang lebih kompetitif, dan meningkatkan kualitas produksi untuk menaikan daya saing di dalam dan luar negeri. Berdasarkan data yang dirilis oleh Badan Pusat Statistik dan dilihat dari data Un Comtrade nilai ekspor alas kaki Indonesia sepanjang tahun 2018 tercatat sebesar $\$ 5,11$ atau setara dengan Rp. 71 triliun. Capaian ini adalah tingkat ekspor industri alas kaki tertinggi yang pernah dimiliki Indonesia. Namun, capaian ini masih jauh dengan target yang dituju oleh kementrian perindustrian Indonesia yaitu pertumbuhan sebesar $10 \%$ setiap tahunnya.

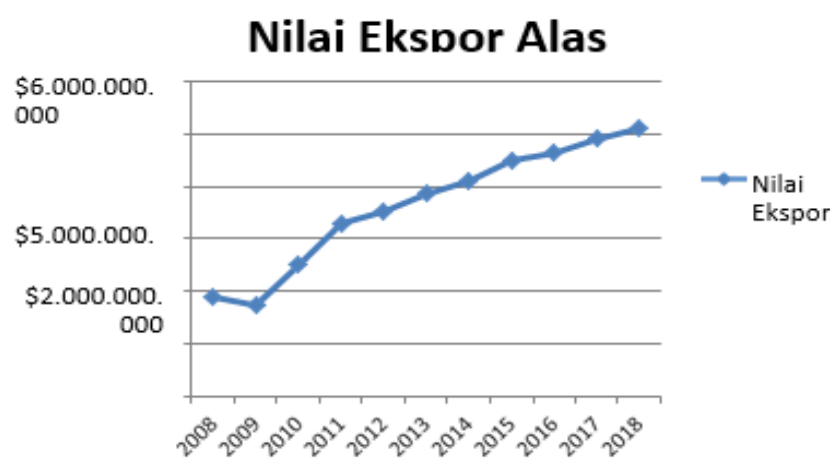

Gambar 2. Ekspor Alas Kaki Menurut Negara Tujuan Utama (ton)

Jika dilihat dari grafik di atas, negara- negara yang menjadi pasarutama dalam kegiatan ekspor alas 
kaki Indonesia antara lain Amerika Serikat, Inggris, Belgia, Jepang, Jerman dan Italia. Jika dilihat, jumlah ekspor naik pada tahun 2016 ke negara Tiongkok dan tingkat ekspor menjadi tinggi ke negara tersebut, menjadikan Tiongkok pasar utama juga dalam ekspor alas kaki. Namun dari keseluruhan negara tersebut, Amerika Serikat merupakan negara yang menjadi tujuan utama kegiatan ekspor Indonesia. Hal ini disebabkan karena besarnya kontribusi dari nilai ekspor alas kaki Indonesia yang cukup tinggi ke negara tersebut dibandingkan nilai ekspor ke negara lainnya. Hal inilah yang menjadi dasar dari penelitian ini.

Dalam melihat daya saing suatu produk, maka diperlukan indikator sebagai tolak ukur antara yang satu dengan lainnya. Salah satu indikatorberhasilnya suatu produk dalam persaingan adalah semakin lakunya produk tersebut di pasaran, yang dapat ditandai dengan semakin meningkatnya penjualan atau dalam perdagangan internasional semakin meningkatnya produk ekspor tersebut. Kemudian kualitas dan mutu dari suatu produk juga merupakan indikator dalam mengukur daya saing, yaitu jika suatu produk memiliki tampilan dan daya tahan yang baik maka akan semakin tinggi daya saing nya dan juga suatu produk dikatakan memiliki kualitas apabila produk tersebut mampu menyesuaikan dengan kebutuhan pasar. Pola keunggulan komparatif pun mulai menunjukkan kecenderungan ke arah yang sesuai ke arah proporsi faktor produksi Indonesia. Indonesia meraih daya saing industri manufaktur padat sumber daya alam sejak tahun 1983. Hal ini ditandai oleh Revealed Comparative Advantage (RCA) yang melewati angka 1.

RCA adalah indeks yang mengukur kinerja ekspor suatu komoditas dari satu negara dengan mengevaluasi peranan ekspor total negara tersebut, dibandingkan dengan pangsa komoditas tersebut dalam perdagangan dunia. Nilai indeks yang lebih dari satu menunjukkan pangsa pasar komoditas yang diekspor di dalam total ekspor suatu negara lebih besar daripada pangsa rata- rata dari komoditas yang bersangkutan dalam ekspor semua negara (dunia).

\section{METODOLOGI PENELITIAN}

Dalam penelitian ini penelitian menggunakan metode pendekatan penelitian secara kuantitatif. Metode kuantitatif adalah metode penelitian yang dapat diartikan sebagai metode penelitian yang berlandaskan pada filsafat positivisme, digunakan untuk meneliti pada populasi atau sampel tertentu, pengumpulan data menggunakan instrumen penelitian, analisis data bersifat kuantitatif atau statistik, dengan tujuan untuk menguji hipotesis yang telah ditetapkan.

Dalam penelitian ini penulis menggunakan data time series. Time series merupakan data yang disusun berdasarkan runtun waktu, seperti data harian, mingguan, bulanan atau tahunan. Penelitian ini menggunakan data tahunan. Dilihat dari sifatnya penelitian ini bersifat Asosiatif (Hubungan), yaitu suatu metode penelitian yang bertujuan untuk mengetahui hubungan antara dua variabel atau lebih, dimana penelitian ini bertujuan untuk mengetahui hubungan pengaruh antara variabel bebas terhadap variabel terikat.

Adapun data yang digunakan dalam penelitian ini adalah data sekunder. Sumber data dalam penelitian ini yaitu dari publikasi BPS (Badan Pusat Statistik) Republik Indonesia, World Bank, Bank Indonesia, dan UnComtrade. Data yang diambil dari publikasi BPS Republik Indonesia dan UnComtrade yaitu data ekspor alas kaki di Indonesia, data produksi Indonesia diambil dari Badan Pusat Statistik Inodonesia. Sedangkan data GDP Amerika diambil dari world bank dan data nilai tukar diambil dari Bank Indonesia, data harga komoditas ekspor dari World Footwear Yearbook.

Teknik pengambilan sampel yang digunakan pada penelitian ini adalah secara purposive sampling yaitu teknik penentuan sampel dengan pertimbangan tertentu Kriteria pengambilan sampel adalah sebagai berikut:

a. Penelitian mengenai daya saing

1) Nilai ekspor alas kaki Indonesia ke Amerika Serikat $2008-2018$.

2) Nilai total ekspor Indonesia ke Amerika Serikat $2008-2018$.

3) Nilai ekspor alas kaki dunia ke Amerika Serikat $2008-2018$.

4) Nilai ekspor dunia ke Amerika Serikat 2008 $-2018$.

b. Penelitian mengenai faktor-faktor yang mempengaruhi ekspor alas kaki

1) GDP Amerika Serikat periode 2008 - 2018.

2) Nilai Tukar rupiah terhadap US\$ periode 2008 - 2018.

3) Harga Alas Kaki Internasional periode 2008 $-2018$.

4) Produksi Alas Kaki Indonesia periode 2008 $-2018$.

5) Ekspor alas kaki Indonesia ke Amerika Serikat periode $2008-2018$. 


\section{LANDASAN TEORI}

\subsection{Perdagangan Internasional}

Perdagangan internasional adalah suatu kegiatan jual beli untuk memperoleh keuntungan (perdagangan) yang dilakukan dengan melibatkan unsur-unsur dua negara atau lebih (internasional). Kalau diperluas makna memperoleh keuntungannya tidak selalu keuntungan secara finansial tetapi juga bisa keuntungan nonfinansial seperti untuk kepentingan promosi, persaingan usaha dan keuntungan strategis lainnya. Perdagangan internasional dapat didefinisikan sebagai aktivitas perdagangan yang dilakukan oleh penduduk suatu negara dengan penduduk negara lain atas dasar kesepakatan bersama. Penduduk negara yang dimaksud adalah merupakan individu dengan individu, antara individu dengan pemerintah suatu negara atau pemerintah suatu negara dengan pemerintah negara lain. Secara teoritis, perdagangan internasional terjadi karena dua alasan utama, yaitu: yang pertama negara-negara berdagang karena pada dasarnya mereka berbeda satu sama lain. Setiap negara dapat memperoleh keuntungan dengan melakukan sesuatu yang relatif lebih baik. Yang kedua, negara-negara melakukan perdagangan dengan tujuan untuk mencapai skala ekonomi (economics of scale) dalam produksi.

\subsection{Daya Saing}

Daya saing adalah suatu konsep yang digunakan dalam menilai kemampuan suatu wilayah atau negara dalam memproduksi barang atau produk yang lebih unggul dari dari wilayah atau negara yang lainnya. Konsep daya saing berpijak dari konsep keunggulan komparatif yang pertama kali dikenal dengan model Ricardian. Hukum keunggulan komparatif (The Law of Comparative Advantage) dari Ricardo menyatakan bahwa sekalipun suatu negara tidak memiliki keunggulan absolut dalam memproduksi dua jenis komoditas jika dibandingkan negara lain, namun perdagangan yang saling menguntungkan masih bisa berlangsung, selama rasio harga antar negara masih berbeda jika dibandingkan tidak ada perdagangan. Ricardo menganggap keabsahan teori nilai berdasar tenaga kerja (labor theory of value) yang menyatakan bahwa hanya satu faktor produksi yang penting yang menentukan nilai suatu komoditas yaitu tenaga kerja. Nilai suatu komoditas adalah proporsional (secara langsung) dengan jumlah tenaga kerja yang diperlukan untuk menghasilkannya. Salah satu kelemahan teori Ricardo adalah tenaga kerja adalah satu-satunya faktor produksi, output persatuan input tenaga kerja dianggap konstan.

\subsection{Teori Daya Saing}

a. Model Berlian Daya Saing Internasional (Michael E. Porter)

Teori keunggulan kompetitif yang dikembangkan oleh Michael E. Porter guru besar pada Harvad Business School, cara pendekatannya berbeda dengan para ahli ekonomi makro pada umumnya. Porter bertitik tolak pada dari kenyataan-kenyataan persaingan internasional yang ada, jadi pembentukan teorinya adalah deduktif. Porter mengembangkan model yang dikenal sebagai model Berlian, menerangkan bahwa suatu negara secara nasional dapat meraih keunggulan kompetitif, apabila dipenuhi empat persyaratan yang saling terkait dan membentuk empat titik sudut dari poin yang dinamakan bangunan intan, yakni seperti berikut:

1) Keadaan faktor-faktor produksi, seperti tenaga kerja terampil atau prasarana.

2) Keadaan permintaan dan tututan mutu di dalam negeri untuk hasil industri tertentu.

3) Eksistensi industri terkait dan pendukung yang kompetitif secara internasional.

4) Strategi perusahaan itu sendiri dan struktur serta sistem persaingan antar perusahaan.

b. Daya Saing Internasional Berdasarkan Model 9 Faktor (Dong-Sung Cho)

Dong-Sung Cho, presiden dari The Institute of Indusrial Policy Studies, Korea Selatan, dalam karya cemerlangnya yang berjudul Determinan of International Competitiveness: How Can a Developing Country Transform Itself to an Advance Economy? melengkapi hasil kajian dari Michael E. Porter. Dong-Sung Cho menjelaskan bahwa bukannya seberapa banyak tingkat sumber daya yang sekarang dimiliki oleh sebuah negara, tetapi siapa yang bisa menciptakan sumber daya dan kapan seharusnya sumber daya itu diciptakan. Dong-Sung Cho kemudian mengembangkan model yang dikenal sebagai model 9 faktor. Beberapa perbedaan antara model berlian yang dikembangkan oleh Porter dibanding dengan model 9 faktor dari Dong-Sung Cho adalah terletak pada keberadaan 4 faktor, yaitu meliputi tenaga kerja, birokrasi dan politisi, kewirausahaan dan manajer, teknisi serta perancang profesional. Juga faktor akses dan kesempatan dalam melakukan sesuatu bagi 
masyarakat merupakan faktor tidak kalah penting dalam mempertajam daya saing internasional.

\subsection{Gross Domestic Product (GDP)}

Produk Domestik Bruto (PDB) atau Gross Domestic Product (GDP) didefinisikan sebagai total pendapatan yang dihasilkan semua orang baik warga negara sendiri maupun warga negara asing dari semua barang dan jasa di dalam suatu negara. PDB mengukur nilai semua barang dan jasa yang dihasilkan di dalam negeri (domestik) tanpa membedakan kepemilikan/ kewarganegaraan dalam periode tertentu.

Gross Domestic Product (GDP) menghitung hasil produksi suatu perekonomian tanpa memerhatikan siapa pemilik faktor produksi tersebut. Semua faktor produksi yang berlokasi dalam perekonomian tersebut output- nya diperhitungkan dalam GDP. Akibatnya, PDB kurang memberikan gambaran tentang berapa sebenarnya output yang dihasilkan oleh faktor- faktor produksi milik perekonomian domestik. Berikut adalah tiga cara pendekatan perhitungan GDP atau PDB:

a. Pendekatan Pendapatan

Pendekatan pendapatan adalah metode atau cara menghitung PDB dengan menghitung pendapatan seperti upah, sewa, bunga dan laba yang diterima oleh setiap faktor produksi dalam menghasilkan barang akhir.

\section{Rumus:}

PDB = Pendapatan nasional + Depresiasi + (Pajak Tidak Langsung - Subsidi) + Pembayaran Faktor Netto Kepada Luar Negeri

Komponen pendekatan pendapatan:

1) Pendapatan nasional adalah total pendaptan yang diterima oleh faktor produksi di dalam suatu negara. Pendapatan nasional meliputi keuntungan perusahaan, kompensasi pegawai, bunga bersih, dan pendapatan sewa.

2) Depresiasi atau penyusutan dari modal aktiva, disebut dengan penurunan nilai.

3) Pajak tidak langsung, misalnya pajak penjualan, bea cukai, biaya lisensi. Subsidi adalah pembayaran oleh pemerintah tanpa memperoleh imbalan barang atau jasa.

4) Pembayaran faktor netto untuk luar negeri adalah pembayaran pendapatan atas faktor produksi untuk luar negeri dikurangi penerimaan pendapatan faktor dari luar negeri. b. Pendekatan Pengeluaran

Pendekatan pengeluaran adalah cara menghitung PDB dengan mengukur jumlah pengeluaran atas semua barang akhir pada kurun waktu tertentu (umumnya satu tahun).

\section{Rumus:}

PDB $=$ Konsumsi + Investasi + (Konsumsi dan Investasi Pemerintah) + (Ekspor - Impor).

Komponen pendekatan pengeluaran:

1) Konsumsi pada PDB adalah konsumsi dari rumah tangga atau pribadi, yaitu jasa, barang tahan lama, barang tidak tahan lama.

2) Investasi dari rumah tangga atau perusahaan untuk modal baru, misalnya pabrik, persediaan, peralatan, dan lainnya.

3) Konsumsi dan investasi pemerintah meliputi pemerintah federal, negara bagian, pemerintah lokal, untuk memberi jasa dan barang- barang akhir.

4) Ekspor netto merupakan selisih antara ekspor dan impor.

\subsection{Nilai Tukar}

Nilai tukar mata uang merupakan perbandingan nilai dua mata uang yang berbeda atau dikenal dengan sebutan kurs. Nilai tukar atau kurs (foreign exchange rate) dapat didefinisikan sebagai harga mata uang suatu negara relatif terhadap mata uang negara lain. Karena nilai tukar ini mencakup dua mata uang, maka titik keseimbangan ditentukan oleh sisi penawaran dan permintaan dari kedua mata uang tersebut, atau dengan kata lain nilai tukar adalah sejumlah uang dari suatu mata uang tertentu yang dapat dipertukarkan dengan satu unit mata uang negara lain.

\section{a. Nilai Tukar Tetap (Fixed Exchange Rate)}

Sistem nilai tukar tetap adalah nilai tukar mata uang yang dibuat konstan ataupun hanya diperbolehkan berfluktuasi pada rentang yang sempit. Bila pada suatu saat nilai tukar mulai berfluktuasi terlalu besar, maka pemerintah akan melakukan intervensi untuk menjaga agar fluktuasi tetap berada dalam kisaran yang diinginkan.

b. Nilai Tukar Mengambang (Floating Exchange Rate)

Nilai tukar mengambang atau sering disebut floating exchange rate adalah di mana tingkat nilai tukar dibiarkan menurut keseimbangan permintaan dan penawaran mata uang asing yang 
terjadi. Pada kondisi nilai tukar mengambang, nilai tukar akan disesuaikan secara terus-menerus sesuai dengan kondisi penawaran dan permintaan dari mata uang tersebut.

c. Nilai Tukar Terikat (Pegged Exchange Rate)

Sistem nilai tukar terikat adalah sistem di mana mata uang lokal diikatkan nilainya pada sebuah valuta asing atau pada sebuah jenis mata uang tertentu.

\subsection{Harga Komoditas Ekspor}

Harga adalah suatu nilai tukar dari produk barang maupun jasa yang dinyatakan dalam satuan moneter Harga suatu barang ekspor merupakan variabel penting dalam merencanakan perdagangan internasional.

\subsection{Teori Harga}

Teori permintaan menerangkan tentang ciri hubungan antara jumlah permintaan dan harga. Hukum permintaan menjelaskan sifat hubungan antara permintaan suatu barang dengan tingkat harganya. Hukum permintaan pada hakikatnya merupakan suatu hipotesis yang menyatakan makin rendah harga suatu barang maka makin banyak permintaan terhadap barang tersebut.

\subsection{Ekspor}

Ekspor adalah penjualan barang ke luar negeri dengan menggunakan sistem pembayaran, kualitas, kuantitas dan syarat penjualan lainnya yang telah disetujui oleh pihak eksportir dan importir Proses ekspor pada umumnya adalah tindakan untuk mengeluarkan barang atau komoditas dari dalam negeri untuk memasukannya ke negara lain. ekspor adalah kegiatan penjualan suatu barang yang dikirimkan ke luar dari negara satu ke negara yang lainnya dengan prosedur tertentu yang telah disepakati oleh negara-negara tersebut.

\subsection{Daya Saing dan Faktor-faktor yang Mempengaruhi Ekspor Perspektif Ekonomi Islam}

Islam menganjurkan umatnya untuk melakukan perlombaan dalam mencari kebaikan. Firman Allah SWT dalam surat Al-Baqarah ayat 148Artinya:

"Dan setiap umat mempunyai kiblat yang dia menghadap kepadanya. Maka berlombalombalah kamu dalam kebaikan. Di mana saja kamu berada, pasti Allah akan mengumpulkan kamu semuanya. Sungguh, Allah Maha Kuasa atas segala sesuatu. "(Q.S Al-Baqarah: 148)
Jika ini dijadikan sebagai dasar bisnis, maka praktek bisnis harus menjalankan aktivitas persaingan yang sehat. Menurut Muhammad Ismail Yusanto dan Muhammad Karebet Widjajakusuma dalam buku yang berjudul Menggagas Bisnis Islami terdapat penjelasan bahwa persainganbisnis yang sehat dalam Islam minimal ada tiga unsur yang harus dicermati, yaitu:

a. Pihak-pihak yang bersaing. Dalam Islam bersaing adalah memberikan yang terbaik dalam bisnis bukan untuk mematikan pesaing atau hanya sekedar memenangkan persaingan.

b. Segi cara bersaing. Memberikan pelayanan terbaik (service excellent), tidak memberikan suap, tidak memanipulasi produk, jujur dengan kualitas produk, dan tidak diperkenankan memberikan fasilitas khusus pada seseorang atau sekelompok bisnis misalnya tentang teknologi, informasi pasar, pasokan bahan baku, dan penghapusan pajak.

c. Produk yang dipersaingkan. Produk yang dipersaingkan harus halal, tidak diperkenankan membanting harga dengan tujuan menjatuhkan pesaing, dan tempat yang digunakan harus bebas dari hal-hal yang diharamkan, dan tidak memberikan pelayanan yang mengundang maksiat.

\subsection{Nilai Tukar Dalam Perspektif Ekonomi Islam}

Dalam ekonomi Islam, aktivitas pertukaran mata uang atau nilai tukar disebut dengan sharf. Dimana aktivitas tersebut hukumnya mubah. Sharf adalah jual beli atau pertukaran antara satu mata uang dengan mata uang asing yang lainnya.

\subsection{Produksi}

Istilah Produksi sering digunakan dalam term membuat sesuatu. Secara khusus, produksi adalah kegiatan untuk menciptakan atau menambah suatu barang atau jasa. Dalam istilah yang lebih luas dan lebih fundamental, produksi dapat diartikan sebagai pengubahan bahan-bahan dari sumber-sumber menjadi hasil yang diinginkan oleh konsumen. Hasil itu dapat berupa barang atau jasa.

Dalam pengertian sederhana, produksi berarti menghasilkan barang atau jasa. Menurut ilmu ekonomi, pengertian produksi adalah kegiatan menghasilkan barang maupun jasa atau kegiatan menambah nilai keguanaan atau manfaat suatu barang. 


\section{HASIL DAN PEMBAHASAN}

4.1. Berdasarkan analisis revealed comparative advantage ( $R C A)$ yang diperoleh Indonesia hasil rata-rata memilikiindeks RCA sebesar 1,087, hasil tersebut lebih besar dari 1. Hal ini sesuai dengan hipotesis, artinya pangsa ekspor alas kaki Indonesia terhadap total ekspor Indonesia lebih besar daripada pangsa rata-rata ekspor dunia dengan kata lain ekspor alas kaki Indonesia memiliki daya saing. Lalu, indeks RCA Indonesia dikomparasikan dengan pesaing-pesaing Indonesia yang termasuk dalam 4 top exporters. Hasil analisis yang didapatkan yaitu Cina memiliki indeks RCA sebesar 0,977, Vietnam memiliki indeks RCA sebesar 1,032 dan Jerman memiliki indeks sebesar 1,016. Dari hasil tersebut dapat disimpulkan bahwa Indonesia menjadi top exporter dengan hasil indeks RCA tertinggi pada ekspor alas kaki ke Amerika Serikat. Peringkat kedua ada pada negara Vietnam denga hasil indeks RCA sebesar 1,032. Peringkat ketiga yaitu Jerman dengan indeks RCA sebesar 1,016. Peringkat keempat yaitu Cina dengan nilai indeks RCA sebesr 0,977.

4.2. Hasil penelitian secara parsial, GDP AS memperoleh koefisien 4,125521 dengan taraf signifikasi sebesar 0,0280 yang berarti GDP AS berpengaruh positif dan signifikan terhadap ekspor alas kaki Indonesia. Variabel nilai tukar memperoleh koefisien 0,634096 dengan taraf signifikasi 0,0242 yang berarti nilai tukar berpengaruh positif dan signifikan terhadap ekspor alas kaki Indonesia. Variabel harga memperoleh koefisien sebesar 0,015180 dengan taraf signifikasi 0,9391 yang artinya harga memiliki pengaruh positif namun tidak signifikan terhadap ekspor alas kaki Indonesia. Variabel produksi memperoleh koefisien sebesar 0,018501 dengan taraf signifikasi 0,7809 yang artinya produksi berpengaruh negatif dan tidak signifikan terhadap ekspor alas kaki Indonesia. Berdasarkan penjelasan tersebut maka dapat disimpulkan bahwa faktor-faktor yang mempengaruhi ekspor alas kaki Indonesia tahun 2008 - 2018 bedasarkan penelitian ini yaitu GDP AS dan nilai tukar. Sedangkan berdasarkan uji simultan diperoleh hasil Prob ( $F$-statistic) yaitu 0,028242 yang artinya variabel GDP AS, nilai tukar, harga komoditas ekspor dan produksi secara bersama-sama berpengaruh terhadap ekspor alas kaki Indonesia pada tahun 2008 2018.

4.3. Dalam ekonomi Islam, persaingan sangatlah diperbolehkan. Persaingan yang diperbolehkan adalah persaingan secara sehat sebagaimana telah disebutkan dalam Q.S Al-Baqarah ayat 148. Perdagangan internasional perspektif ekonomi Islam melarang praktek dumping dalam melakukan transaksi. Hal ini bertujuan untuk menghindari mudharat dalam transaksi yang dilakukan oleh negara pengimpor dan pengekspor barang. Ekspor alas kaki Indonesia ke Amerika Serikat telah sesuai dengan perspektif ekonomi Islam meskipun negara tujuan bukanlah negara yang mayoritas penduduknya muslim. Ini ditunjukkan oleh perjanjian perdagangan yang telah disepakati oleh kedua negara yaitu hukum ramah lingkungan dan anti dumping.

\section{REKOMENDASI}

5.1. Bagi pemerintah, penelitian ini diharapkan dapat untuk memberikan gambaran atas kebijakan yang harus diambil. Untuk meningkatkan pertumbuhan ekspor alas kaki sebesar 10\% pertahun, Pemerintah disarankan untuk meningkatkan target ekspor alas kaki ke negara pengimpor alas kaki Indonesia tertinggi yaitu Amerika Serikat dengan meningkatkan kualitas alas kaki atau paling tidak menjaga kualitasnya.

5.2. Setelah diteliti GDP negara tujuan mempengaruhi ekspor alas kaki, maka dapat disarankan untuk memperluas pangsa pasar pada negara-negara yang memiliki GDP yang tinggi di dunia agar dapat meningkatkan ekspor alas kaki Indonesia. Selain itu, meskipun semakin tinggi nilai dollar AS terhadap rupiah pada variabel nilai tukar, semakin tinggi ekspor alas kaki Indoenesia ke Amerika Serikat, namun bukan berarti hal ini merupakan sesuatu yang harus dipertahankan oleh Indonesia, menjaga kestabilan nilai tukar rupiah terhadap dollar AS juga tidak kalah penting dalam rangka mencapai target pertumbuhan ekspor alas kaki sebesar 10\% tiap tahunnya dan menjaga pengaruh pada aspekaspek ekonomi lainnya yang disebabkan karena melemahnya rupiah terhadap dollar. Selanjutnya, jika harga tidak berpengaruh terhadap ekspor alas kaki ke Amerika Serikat, bukan berarti perusahaan dapat meninggikan harga sesukanya, meminimkan harga jual juga disarankan. Apabila 
harga semakin murah, bukan hanya negara Amerika Serikat saja yang tertarik untuk membeli produk alas kaki Indonesia, namun negara - negara lain pun dapat semakin tertarik dengan produk alas kaki Indonesia.

5.3. Bagi akademisi dan peneliti selanjutnya, dengan diperoleh hasil penelitian ini diharapkan dapat dijadikan sebuah bahan referensi untuk kegiatan mengajar dan penelitian. Diharapkan juga pada penelitian selanjutnya dapat mengubah tujuan ekspor (negara selain Amerika Serikat), tujuannya adalah untuk mengetahui daya saing ekspor alas kaki Indonesia di dunia dengan tujuan ekspor negara lain. Peneliti selanjutnya diharapkan untuk mengubah atau menambah analisis RCA ekspor alas kaki pada negara lainnya yang termasuk ke dalam top 10 exporters pada ekspor alas kaki, menambah variabelvariabel lain atau mengganti variabel-variabel yang tidak signifikan dalam penelitian ini. Sehingga dapat mengetahui bagaimana daya saing negara lain dalam ekspor alas kaki dan memberikan hasil yang lebih benar-benar menggambarkan hal-hal apa saja yang dapat mempengaruhi ekspor alas kaki Indonesia dengan varibel- variabel lain yang di teliti dan diharapkan dapat memperpanjang periode penelitian.

\section{REFERENSI}

\section{Buku dan Majalah}

Abdul Aziz, Ekonomi Islam Analisis Mikro dan Makro, Yogyakarta: Graha Ilmu 2008.

Adiwarman Azwar Karim, Sejarah pemikiran Ekonomi Islam, Jakarta: PT Raja Grafindo Persada, 2010.

, Ekonomi Makro Islami, Jakarta: PT. Raja Grafindo Persada, 2007.

Ali Ibrahim Hasyim, Ekonomi Makro, Jakarta: PT Fajar Interpratama Mandiri,2016.

Atep Endang Waluya, "Perdagangan Internasional dalam Islam". Majalah Tabligh No. 4/XIV, 14 Agustus 2019.

Basri F, Dasar-dasar Ekonomi Internasional, Jakarta: Kencana Prenada MediaGroup, 2010.

Bhuono Agung Nugroho, Strategi Jitu Memilih Metode Statistik Penelitian Dengan SPSS, CV Andi Offset, 2005.
Departemen Pendidikan Nasional, Kamus Besar Indonesia Pusat Bahasa, Jakarta : PT Gramedia Pustaka Utama, 2011.

Departemen Agama RI, Al-Qur'an dan Terjemahannya, Bandung: CV. Penerbit Diponegoro, 2010.

Detri Karya, Syamri Syamsudin, Makroekonomi pengantar untuk manajemen, Jakarta: PT Raja Grafindo Persada, 2017.

Eko Suprayitno, Ekonomi Mikro Perspektif Islam, Yogyakarta: UIN-MalangPress, 2008.

Harry Waluya, Ekonomi Internasional, Jakarta: PT Rineka Cipta, 2003.

Hendra Halwani, Ekonomi Internasional dan Globalisasi Ekonomi Edisi Kedua,Bogor: Ghalia Indonesia, 2005.

Faisal H Basri, Perekonomian Indonesia, Jakarta: Erlangga, 2002.

Fandi Tjiptono, Pemasaran Jasa prinsip, penerapan dan penelitian, Yogyakarta: CV Andi Offset, 2014.

Ferry Syarifuddin, Konsep, Dinamika dan Respon Kebijakan Nilai Tukar di Indonesia, Jakarta: Bank Indonesia Institute, 2016.

Samsul Basri, Ekonomi dan Bisnis Islam, Jakarta: PT Raja Grafindo Persada,2016.

Imam Ghozali, Aplikasi Analisis Multivariate dengan Program IBM SPSS23,Semarang: Badan Penerbit UNDIP, 2016.

J. Supranto, Metode Penelitian Ramalan Kuantitatif Untuk Perencanaan Ekonomidan Bisnis Jakarta: Rineka Cipta, 2000.

Kasmir, Perbankan Syari'ah, Jakarta: Kencana, 2013. , Kewirausahaan, Depok: Raja Grafindo Persada, 2013. Mahyus Ekananda, Ekonomi Internasional, Jakarta: Erlangga, 2014.

Muhamad, Amin Suma, Tafsir Ayat Ekonomi Teks, Terjemahan Dan Tafsir,Jakarta: Amzah, 2005.

Muhammad Ismail Yusanto, Muhammad Karebet Widjajajkusuma, Mengaggas Bisnis Islami, Jakarta: Gema Insani Press, 2002.

Muhammad Sharif Chaudhry, Sistem Ekonomi Islam: Prinsip Dasar, Jakarta:Kencana, 2012.

Nopirin, Ekonomi Moneter Buku I Edisi keempat, Penerbit BPFE: Yogyakarta,2011.

Nurul Zariah, Metode Penelitian Sosial dan Pendidikan, Jakarta: Bumi aksara,2007.

Philip Kotler dan Kevin Lane Keller, Manajemen Pemasaran Edisi ketiga belas,Jakarta : Erlangga, 2008. 
Prathama Rahardja, Mandala Manurung, Pengantar Ilmu Ekonomi, Jakarta:Fakultas Ekonomi UI, 2008.

Pusat Pengkajian dan Pengembangan Ekonomi Islam, Ekonomi Islam, Jakarta: PT Raja Grafindo Persada, 2011.

Rahardjo Adisasmita, Teori-teori Pembangunan Ekonomi Cetakan Pertama,Yogyakarta: Graha Ilmu, 2013.

Rahmat Sunnara, Islam dan Ekonomi, Jakarta: Buana Cipta Pustaka, 2009.

Sabiq. Sayyid, Fiqh Sunah Sayyid Sabiq Jilid 3, Jakarta Timur: Al-I'tishom 2010.

Sadono Sukirno, Mikroekonomi Teori Pengantar Edisi Ketiga, Jakarta: Raja Grafindo Persada, 2016.

, Makroekonomi Teori Pengantar Edisi Ketiga, Jakarta: Raja GrafindoPersada, 2016.

Sugiyono, Metode Penelitian Kuantitatif, kualitatif, dan Kombinasi Mixed Methods, Bandung: Alfabet, 2017.

Tulus T.H Tambunan, Perekonomian Indonesia, Bogor: Ghalia Indonesia, 2011.

V. Wiratna Sujarweni, Metode Penelitian Bisnis dan Ekonomi, Cetakan PertamaYogyakarta: Pustaka Baru Perss, 2015.

Wijayanto, Market Brief Produk Footwear, Chicago: Indonesian Trade Promotion Center, 2014.

Windhu Putra, Perekonomian Indonesia, Depok: PT Raja Grafindo Persada, 2018.

Wing Wahyu Winarno, Analisis Ekonometrika dan Statistika dengan Eviews, Yogyakarta: UPP STIM YKPN, 2017.

\section{Jurnal dan Tesis}

Achmad Lubabul Chadziq, "Perdagangan Internasional Studi Komparasi Perdagangan Internasional Konvensional dan Islam". Akademika, Vol. 10 No. 2 Desember 2016.

Aldo Gunawan, "Pengaruh Harga Internasional, Nilai Tukar Dan Gdp Perkapita Amerika Serikat Terhadap Nilai Ekspor Tekstil Indonesia Ke Amerika Serikat”. Jurnal Ekonomi Pembangunan, Vol. 1 No. 4 September 2013.

Ali Wardhana, "Analisis Faktor-Faktor yang Mempengaruhi Ekspor Nonmigas Indonesia Ke Singapura Tahun 1990 - 2010”. Jurnal Manajemen dan Akuntansi, Vol. 12 No. 2 Oktober 2011.
Budi Yasri, “Analisis Kinerja Ekspor Non Migas Indonesia ke Uni Eropa". Jurnal Ilmiah Edukasi, Vol. 4 No. 3, Agustus 2016.

Damara Vikiyanto, "Faktor-Faktor yang Mempengaruhi Ekspor Alas Kaki Indonesia ke Amerika Serikat". Journal of Economics and Business, Vol. 1 No. 1 Mei 2019.

Dinan Arya Putra, "Analisis Faktor-faktor yang Mempengaruhi Ekspor Tembakau Indonesia ke Jerman". Economics Development Analysis Journal, Vol. 2 No. 3 Agustus 2013.

Dewi Anggraini,"Faktor-Fktor Yang Mempengaruhi Permintaan Ekspor Kopi Indonesia Dari Amerika Serikat”. Tesis Program Magister Ilmu Ekonomi dan Studi Pembangunan Universitas Diponegoro, Semarang, 2006.

Farid Ustriadi, "Analisis Daya Saing Komoditi Ekspor Unggulan Indonesia di Pasar Internasional". Jurnal Ekonomi Pembangunan, Vol. 14 No. 02 Desember 2016.

Hakim Muda Harahap, "Epistimologi Etika Perdagangan Internasional Dalam Konsep AlQur'an". Jurnal Studi Al-Qur'an dan Hadist, Vol. 3 No. 2 November 2019.

I Kadek Krisna, I Wayan Wita Kesuma, "Analisis Tingkat Daya Saing dan Faktor-Faktor yang Mempengaruhi Ekspor Kayu Olahan Ke Negara Amerika Serikat". Jurnal Ekonomi Pembangunan, Vol. 2 No. 6 Juni 2013.

I Putu Ogi Suparsa, Ni Putu Martini Dewi, “Analisis Daya Saing Ekspor Komoditi Kepiting Provinsi Bali”. Jurnal Ekonomi Pembangunan, Vol. 5 No.6 Juni 2016.

Kadek Mega Silvia Andriani, I Komang Gde Bendesa, "Keunggulan Komparatif Produk Alas Kaki Indonesia Ke Negara ASEAN Tahun 2013". Jurnal Ekonomi Kuantitatif Terapan, Vol. 8 No. 2 Agustus 2015.

Leni Saleh, "Perubahan Nilai Tukar Uang Menurut Perspektif Ekonomi Islam". Jurnal Studi Ekonomi dan Bisnis Islam, Vol. 1 No. 1 Juni 2016, mengutip An-Nabhani, Taqyuddin, Membangun Sistem Ekonomi Alternatif Perspektif Islam, Surabaya: Penerbit Risalah Gusti, 1999.

Lutvi Fauziana dkk, "Keterkaitan Investasi Modal Terhadap GDP Indonesia". Jurnal Ekonomi Pembangunan, Vol. 3 No. 2 Juni 2014. 
Mia Ayu Wardani, Sri Mulatsih, “Analisis Daya Saing Dan Faktor-Faktor Yang Memengaruhi Ekspor Ban Indonesia Ke Kawasan Amerika Latin”. Jurnal Ekonomi dan Kebijakan Pembangunan, Vol 6 No.1, Juli 2017.

Muhammad Ismail Yusanto, Muhammad Karebet Widjajakusuma, Menggagas Bisnis Islami, Jakarta: Gema Insani Press, 2002.

Muhammad Luqman Zakariya dkk, "pengaruh produksi, harga, dan nilai tukar terhadap volume ekspor Studi pada Volume Ekspor Biji Kakao Indonesia Periode Januari 2010-Desember 2015. Jurnal Administrasi Bisnis, Vol. 40 No.2 November 2016.

Muhammad Turmudi, "Produksi dalam perspektif ekonomi Islam". Jurnal Pemikiran Islam, Vol. 18 No. 1 Maret 2017.

Nita Anggraeni, "Dumping Dalam Perspektif Hukum Dagang Internasional dan Hukum Islam”. Jurnal Pemikiran Hukum Islam, Vol. 14 No. 2 Desember 2015.

Parell Tua Halomoan Simanjuntak dkk,"Pengaruh Produksi, Harga Internasional Dan Nilai Tukar Rupiah Terhadap Volume Ekspor Rumput Laut Indonesia Studi Pada Tahun 2009 - 2014". Jurnal Administrasi Bisnis, Vol. 50 No. 3 September 2017.

Pradipta A, Posisi Daya Saing dan Faktor-Faktor yang Memengaruhi Ekspor Buah-Buahan Indonesia di Dunia dan Negara Tujuan Bogor : Institut Pertanian Bogor, 2014.

Ribka BR Silitonga dkk, "Pengaruh ekspor, impor, dan inflasi terhadap nilai tukar rupiah di Indonesia”. Jurnal Ekonomi Pembangunan, Vol. 15 No.1, Juni 2017.

Ricky Rinaldi, "Analisis Daya Saing Dan FaktorFaktor Yang Mempengaruhi Aliran Perdagangan Komoditi Unggulan Ekspor Indonesia Ke Afrika Selatan", Tesis Program Ilmu Ekonomi Institut Pertanian Bogor, Bogor, 2014.
Rizki Tri Anugrah Bhakti, "Perlindungan Hukum Oleh Komisi Pengawas Persaingan Usaha Kppu Dari Praktek Dumping Akibat Perdagangan Internasional. Jurnal Cahaya Keadilan, Vol. 6. No. 1 Juni 2015.

Saleh Motana Obadi, "Revealed Comparative Advantage and Competitiveness In the EU-28 and the USA". Economic Review, Vol. 45 No. 2 2016.

Saptana dkk, "Analisis Keunggulan Komparatif Dan Kompetitif Komoditas Kentang Dan Kubis Di Wonosobo Jawa Tengah". Jurnal Ilmu Sosial, Vol. 13 No.1, Oktober 2013.

Sulthon Sjahril Sabaruddin, "Dampak Perdagangan Internasional Indonesia terhadap Kesejahteraan Masyarakat". Buletin Ekonomi Moneter dan Perbankan, Vol 17 No. 4 April 2015.

Supriani Sidabalok, "Analisis Faktor-faktor yang Mempengaruhi Ekspor Komoditas Teh Indonesia”. Jurnal Penelitian Pendidikan Sosial Humaniora, Vol. 2 No. 22017.

Ulul Azmi Mustofa, "Pekerja Yang Handal Menurut Al-Qur'an". Jurnal Ilmiah Ekonomi Islam, Vol. 01 No. 03, November 2015.

Vinny Azaria, Adi Irawan,"Pengaruh Inflasi, Nilai Tukar Rupiah, dan Harga terhadap Volume Ekspor Indonesia Komoditas Kelautan dan Perikanan Menurut Provinsi Periode 2012 2014. Journal Of Applied Managerial Accounting, Vol. 3 No. 1 Maret 2019.

Yunika, "Daya Saing Ekspor Industri Alas Kaki Antara Indonesia Dan China Di Pasar Amerika Serikat Tahun 2011-2014". Jurnal Ilmu Sosial dan Ilmu Politik, Vol. 4 No. 2 Oktober 2017. 